\title{
THE ROLE OF AUTOPSY IN MEDICAL INTENSIVE CARE UNIT: COMPARISON OF CLINICAL AND POSTMORTEM DIAGNOSES
}

\author{
Vandana Tukaram Dahake1, Kavita Khedekar², Felice Faizal3, Nikhil Majethia ${ }^{4}$ \\ ${ }^{1}$ Speciality Medical Officer, Department of Pathology, Dr. R. N. Cooper Hospital, Mumbai. \\ ${ }^{2}$ Associate Professor, Department of Pathology, LTMMC \& GH, Sion. \\ ${ }^{3}$ Speciality Medical Officer, Department of Pathology, Dr. R. N. Cooper Hospital, Mumbai. \\ ${ }^{4}$ Assistant Professor, Department of Pathology, Grant Medical College, Mumbai.
}

ABSTRACT
BACKGROUND
Autopsy is an essential auditing tool in clinical practice. The autopsy teaches us not only what is killing people right now, but
points to what will kill us in the near future. This is the first autopsy study in Medical Intensive Care Unit (MICU) in India as per our
knowledge.

\section{METHODS}

Retro-prospective study of total of 141 medical autopsies of MICU deaths performed in the Department of Pathology during a period of three years. A meticulous study was performed to compare ante-mortem clinical diagnosis and post-mortem final cause of death. Cases showing a discrepancy between the clinical diagnosis and post-mortem final cause of death were categorized into IV classes according to Goldman classification.

\section{RESULTS}

Maximum autopsies were performed in 21-40 years (58.15\%). Female preponderance noted. Non-infectious aetiology was most common cause of death (50\%), of which lesions of respiratory system were the most common (33.8\%). Amongst the infections, pneumonia was the most common cause of death (29.23\%). Discrepancies between ante-mortem and post-mortem were noted in 63 cases (44.68\%). Class I and class II discrepancies were $49.21 \%$ and $44.45 \%$, respectively.

\section{CONCLUSION}

Our study stresses that routine autopsy is still very useful in MICU and emphasis must be placed on autopsy evaluation for the improvement of quality of patient care.

\section{KEYWORDS}

Autopsy, Cause of Death, Clinical Diagnosis, MICU, Postmortem.

HOW TO CITE THIS ARTICLE: Dahake VT, Khedekar K, Faizal F, et al. The role of autopsy in medical intensive care unit: comparison of clinical and postmortem diagnoses. J. Evolution Med. Dent. Sci. 2016;5(20):1038-1042, DOI: 10.14260/jemds/2016/242

\section{INTRODUCTION}

Autopsy is an essential auditing tool in clinical practice. Without the autopsy the radiologist would not see, the clinician would not know and the family would never be sure. Finally, it is only through the autopsy that we are able to define the true sensitivity and specificity of our diagnostic tests. Autopsy remains one of the most reliable methods to validate clinical diagnoses.[1]

Autopsy gives the clinician and the pathologist the opportunity to compare and correlate ante-mortem clinical findings with morphology presented post-mortem. Educationally speaking, the clinicians via autopsy may affirm their medical choices that lead them to a correct diagnosis and identify the false path through which were directed to a wrong one.[2] This is the first autopsy study in Medical Intensive Care Unit (MICU) in India as per our knowledge.

Financial or Other, Competing Interest: None.

Submission 20-01-2016, Peer Review 19-02-2016,

Acceptance 26-02-2016, Published 10-03-2016.

Corresponding Author:

Vandana Tukaram Dahake,

C/o Pradeep T. Dahake,

Flat No-102, HA-Wing,

Shrawandhara Society, Sasane Nagar,

Hadapsar, Pune-411028.

E-mail: vandygmsite@gmail.com

DOI: $10.14260 /$ jemds $/ 2016 / 242$

\section{MATERIAL AND METHODS}

After obtaining Institutional Ethical Committee approval, the present retro-prospective study was carried out in Department of Pathology a Tertiary Care Institute, during the period from June 2011 to May 2014 (3 years' period). A total of 141 adult medical autopsies were done, all were complete autopsies. This study is limited to adult MICU autopsies (12 years and above). All the medical-legal autopsies from MICU have been excluded from the study.

The clinical factors noted in each case from the admission papers: Age, Sex, Duration of MICU stay, Clinical complaints, any relevant finding on general and systemic examination, ante-mortem investigations, clinical diagnoses, etc. The findings were noted from autopsy record of the respective cases: Gross examination of all organs, Provisional cause of death, the microscopic examination findings of every organ in every case including routine haematoxylin-eosin and special stains as per requirement like GMS and PAS, the final cause of death as reported after critical histopathology examination. Cases showing a discrepancy between the clinical diagnosis and post-mortem final cause of death were categorized into IV classes according to Goldman classification (Table 1).[3] 


\begin{tabular}{|c|c|}
\hline Class & Description \\
\hline Class I & $\begin{array}{c}\text { Discrepancy is a missed major diagnosis in } \\
\text { which the principle, underlying cause of death } \\
\text { was missed with probable adverse impact on } \\
\text { survival. }\end{array}$ \\
\hline Class II & $\begin{array}{c}\text { Discrepancy is a missed major diagnosis with } \\
\text { equivocal impact on survival. }\end{array}$ \\
\hline Class & $\begin{array}{c}\text { Non-life threatening diagnosis linked to an } \\
\text { incurable disease, but not immediately } \\
\text { responsible for death. }\end{array}$ \\
\hline Class & $\begin{array}{c}\text { Other types of non-life threatening, non- } \\
\text { diagnosable secondary disease of possible } \\
\text { genetic and epidemiological importance. }\end{array}$ \\
\hline \multicolumn{2}{|c|}{ Table 1: Goldman Classification } \\
\hline
\end{tabular}

(Major discrepancies - Class I and II, Minor discrepancies - Class III and IV).

Our study is an observational study, but the results were statistically analysed using MedCalc version 16.2 wherever necessary.

\section{RESULTS}

In present study, total 3106 cases were admitted to MICU over 3 years' period. MICU mortality rate was $28.14 \%$ (874 of 3106 ) in the span of 3 years. Total number of medical autopsies done in MICU in the span of 3 years were 141. Majority of the autopsied patients in our study were in the age group of 21-40 years, i.e. 82 cases $(58.15 \%)$ and only 3 cases $(2.13 \%)$ were above 60 years. Female preponderance were noted with Male:Female ratio of 1:1.47. The autopsy cases were classified based on the broad etiological head as infectious, noninfectious and neoplastic after histopathological examination. The majority of the cases were due to non-infectious aetiology, 71 cases followed by infectious aetiology, 65 cases and neoplastic were 5 cases. The discrepancies between clinical diagnosis and post-mortem cause of death were 63 (44.68\%).

\begin{tabular}{|c|c|c|c|}
\hline Discrepancy & $\begin{array}{c}\text { Number } \\
\text { of Cases }\end{array}$ & $\begin{array}{c}\text { Percentage } \\
\text { (\%) of total } \\
\text { cases with } \\
\text { discrepancy } \\
(\mathbf{n = 6 3 )}\end{array}$ & $\begin{array}{c}\text { Percentage (\%) } \\
\text { of the cases } \\
\text { compared to } \\
\text { study } \\
\text { population } \\
(\mathbf{n = 1 4 1 )}\end{array}$ \\
\hline Class I & 31 & 49.21 & 21.98 \\
\hline Class II & 28 & 44.45 & 19.86 \\
\hline Class III & 2 & 3.17 & 1.42 \\
\hline Class IV & 2 & 3.17 & 1.42 \\
\hline Total & $\mathbf{6 3}$ & $\mathbf{1 0 0}$ & $\mathbf{4 4 . 6 8}$ \\
\hline \multicolumn{4}{|c|}{ Table 2: Discrepancies Between Clinical } \\
and Post-Mortem Diagnoses
\end{tabular}

\begin{tabular}{|c|c|c|c|c|}
\hline Discrepancy & $\begin{array}{c}<\mathbf{2 4} \\
\text { hrs }\end{array}$ & $\begin{array}{c}\mathbf{2 4 - 4 8} \\
\text { hrs }\end{array}$ & $\begin{array}{c}\mathbf{> 4 8} \\
\text { hrs }\end{array}$ & Total \\
\hline Class I & 13 & 8 & 10 & 31 \\
\hline Class II & 12 & 10 & 6 & 28 \\
\hline Class III & 1 & - & 1 & 2 \\
\hline Class IV & - & 1 & 1 & 2 \\
\hline Total & $\mathbf{2 6}$ & $\mathbf{1 9}$ & $\mathbf{1 8}$ & $\mathbf{6 3}$ \\
\hline Percentage \% & $\mathbf{4 1 . 2 7}$ & $\mathbf{3 1 . 1 6}$ & $\mathbf{2 8 . 5 7}$ & $\mathbf{1 0 0}$ \\
\hline \multicolumn{6}{|c|}{ Table 3: Discrepancy $\mathbf{v}$ s duration of hospital stay } \\
\hline
\end{tabular}

The most of the discrepancies were seen in non-infectious cases, i.e. 33 (52.38\%) followed by infectious, 25 (39.68\%). All the 5 neoplastic cases were missed clinically, which were included in class I and class II errors. Infectious aetiologies showed only class I and class II discrepancies (Table 4 and 5), while non-infectious aetiologies showed all four.

\begin{tabular}{|c|c|c|}
\hline & $\begin{array}{c}\text { Post-mortem cause of } \\
\text { Death }\end{array}$ & Clinical Diagnosis \\
\hline \multirow{5}{*}{$\begin{array}{l}\text { Disseminated } \\
\text { Tuberculosis } \\
\text { (5 cases) }\end{array}$} & $\begin{array}{l}\text { Disseminated } \\
\text { tuberculosis }\end{array}$ & $\begin{array}{c}\text { Haematemesis } \\
\text { secondary to } \\
\text { analgesic, steroid } \\
\end{array}$ \\
\hline & $\begin{array}{l}\text { Disseminated } \\
\text { tuberculosis }\end{array}$ & $\begin{array}{c}\text { Right lung } \\
\text { pneumonia with } \\
\text { sepsis } \\
\end{array}$ \\
\hline & $\begin{array}{c}\text { Disseminated } \\
\text { tuberculosis }\end{array}$ & Chronic diarrhoea \\
\hline & $\begin{array}{c}\text { Disseminated } \\
\text { tuberculosis } \\
\end{array}$ & $\begin{array}{c}\text { Septic shock with } \\
\text { MODS }\end{array}$ \\
\hline & $\begin{array}{c}\text { Bronchopneumonia } \\
\text { with disseminated } \\
\text { abdominal tuberculosis }\end{array}$ & $\begin{array}{l}\text { Acute febrile illness } \\
\text { with hypotension }\end{array}$ \\
\hline \multirow{8}{*}{$\begin{array}{c}\text { Respiratory } \\
\text { causes ( } 8 \text { cases) }\end{array}$} & $\begin{array}{c}\text { Tuberculous } \\
\text { bronchopneumonia }\end{array}$ & AFI \\
\hline & $\begin{array}{c}\text { Tuberculous } \\
\text { bronchopneumonia }\end{array}$ & ARDS \\
\hline & Bronchopneumonia & $\begin{array}{c}\text { Acute demyelinating } \\
\text { polyneuropathy }\end{array}$ \\
\hline & Bronchopneumonia & ARF \\
\hline & Bronchopneumonia & $\begin{array}{c}\text { Cerebral oedema } \\
\text { with intracranial } \\
\text { bleed }\end{array}$ \\
\hline & Lobar pneumonia & $\begin{array}{c}\text { Coronary artery } \\
\text { disease }\end{array}$ \\
\hline & $\begin{array}{c}\text { ARDS \& interstitial } \\
\text { pneumonia }\end{array}$ & $\begin{array}{c}\text { Hepatitis with } \\
\text { hepatic } \\
\text { encephalopathy }\end{array}$ \\
\hline & $\begin{array}{c}\text { Lobar pneumonia with } \\
\text { healed MI }\end{array}$ & Dengue \\
\hline \multirow{4}{*}{$\begin{array}{l}\text { Septicaemia ( } 4 \\
\text { cases) }\end{array}$} & $\begin{array}{c}\text { Septicaemia following } \\
\text { bronchopneumonia }\end{array}$ & MODS \\
\hline & $\begin{array}{c}\text { Septicaemia f/g } \\
\text { multiple pyaemic } \\
\text { abscess of liver }\end{array}$ & AFI with MODS \\
\hline & $\begin{array}{l}\text { Septicaemia with } \\
\text { disseminated } \\
\text { intravascular } \\
\text { coagulation }\end{array}$ & AFI with MODS \\
\hline & $\begin{array}{c}\text { Septicaemia f/g } \\
\text { confluent } \\
\text { bronchopneumonia }\end{array}$ & $\begin{array}{c}\text { Acute demyelinating } \\
\text { polyneuropathy }\end{array}$ \\
\hline \multirow{3}{*}{$\begin{array}{l}\text { Meningitis ( } 3 \\
\text { cases) }\end{array}$} & Tuberculous meningitis & $\begin{array}{c}\text { Lobar pneumonia f/g } \\
\text { aspiration in seizure } \\
\text { disorder }\end{array}$ \\
\hline & $\begin{array}{l}\text { Cerebral oedema f/g } \\
\text { tuberculous meningitis }\end{array}$ & $\begin{array}{c}\text { Sepsis with seizure } \\
\text { disorder }\end{array}$ \\
\hline & $\begin{array}{c}\text { Tuberculous } \\
\text { bronchopneumonia } \\
\text { with tuberculous } \\
\text { meningitis }\end{array}$ & Intestinal obstruction \\
\hline Other (1 case) & $\begin{array}{c}\text { Diffuse alveolar } \\
\text { haemorrhages with } \\
\text { myocarditis, possibly } \\
\text { leptospirosis }\end{array}$ & Pneumonia \\
\hline
\end{tabular}

*Abbreviation: f/g - following, MODS - Multi-organ dysfunction syndrome, AFI - Acute febrile illness, ARDS - Acute respiratory distress syndrome, ARF - Acute renal failure. 


\begin{tabular}{|c|c|}
\hline $\begin{array}{c}\text { Cause of death at } \\
\text { Autopsy }\end{array}$ & Clinical Diagnosis \\
\hline $\begin{array}{c}\text { Interstitial pneumonitis } \\
\text { \& IPH }\end{array}$ & AFI with hypokalaemic paralysis \\
\hline $\begin{array}{c}\text { Haemolytic uremic } \\
\text { syndrome with IPH }\end{array}$ & Acute gastroenteritis with ARF \\
\hline $\begin{array}{c}\text { Septicaemia f/g } \\
\text { confluent lobar } \\
\text { pneumonia }\end{array}$ & Meningitis \\
\hline $\begin{array}{c}\text { Diffuse viral encephalitis } \\
\text { with necrotising } \\
\text { pneumonia }\end{array}$ & $\begin{array}{c}\text { Cerebral malaria with Acute } \\
\text { demyelinating polyneuropathy }\end{array}$ \\
\hline \multicolumn{2}{|c|}{ Table 5: Class II Discrepancy - Infectious Causes (N=4) } \\
\hline
\end{tabular}

*Abbreviation: f/g - following, IPH - intrapulmonary haemorrhage.

Amongst the non-infectious causes, 7 cases were categorised into class I and 22 in class II and 2 each in class III and class IV discrepancies (Table 6 and 7).

\begin{tabular}{|c|c|c|}
\hline & $\begin{array}{c}\text { Cause of death at } \\
\text { Autopsy }\end{array}$ & Clinical Diagnosis \\
\hline \multirow{4}{*}{$\begin{array}{l}\text { Cardio- } \\
\text { vascular } \\
\text { system } \\
(4 \text { cases })\end{array}$} & $\begin{array}{l}\text { CCF with ARDS with } \\
\text { myocardial infarction }\end{array}$ & Myositis with ARF(prerenal) \\
\hline & $\begin{array}{l}\text { Cardiac failure flg } \\
\text { myocardial infarction }\end{array}$ & $\begin{array}{c}\text { Chronic obstructive } \\
\text { pulmonary airway disease } \\
\text { with acute exacerbation with }\end{array}$ \\
\hline & $\begin{array}{l}\text { Cardio-respiratory failure } \\
\text { f/g myocardial infarction }\end{array}$ & MODS \\
\hline & $\begin{array}{l}\text { Cerebral edema with } \\
\text { myocardial infarction }\end{array}$ & $\begin{array}{c}\text { Post-ictal disorientation with } \\
\text { aspirations pneumonia }\end{array}$ \\
\hline \multirow{3}{*}{$\begin{array}{l}\text { Central } \\
\text { nervous } \\
\text { system } \\
\text { lesions } \\
\text { ( } 3 \text { cases) }\end{array}$} & ICT f/g intracranial bleed & $\begin{array}{l}\text { Puerperal sepsis with vivax } \\
\text { malaria }\end{array}$ \\
\hline & $\begin{array}{c}\text { Raised ICT f/g intracranial } \\
\text { bleed with } \\
\text { bronchopneumonia } \\
\end{array}$ & $\begin{array}{c}\text { Acute inflammatory } \\
\text { demyelinating } \\
\text { polyneuropathy } \\
\end{array}$ \\
\hline & $\begin{array}{c}\text { Intracerebral } \\
\text { haemorrhages with lobar } \\
\text { pneumonia with renal } \\
\text { abscess }\end{array}$ & $\begin{array}{c}\text { Plasmodium vivax malaria } \\
\text { with ARF on chronic renal } \\
\text { failure }\end{array}$ \\
\hline \multicolumn{3}{|c|}{ Table 6: Class I Discrepancy - Non-Infectious Causes $(N=7)$} \\
\hline
\end{tabular}

*Abbreviation: CCF - congestive cardiac failure, ICT Raised intracranial tension

\begin{tabular}{|c|c|c|}
\hline & $\begin{array}{c}\text { Post-mortem cause of } \\
\text { Death }\end{array}$ & Clinical Diagnosis \\
\hline \multirow{7}{*}{$\begin{array}{l}\text { Respirato } \\
\text { ry lesions } \\
\text { (8 cases) }\end{array}$} & Diffuse IPH & MODS \\
\hline & (2) Diffuse IPH & (2) AFI with MODS \\
\hline & Diffuse IPH & Renal failure \\
\hline & Diffuse IPH & Cerebral malaria \\
\hline & $\begin{array}{c}\text { Pulmonary edema with } \\
\text { ARDS }\end{array}$ & AFI with sepsis \\
\hline & Pulmonary edema & Hypotensive shock \\
\hline & $\begin{array}{l}\text { Primary pulmonary } \\
\text { hypertension }\end{array}$ & $\begin{array}{l}\text { CAP or pulmonary } \\
\text { Koch's }\end{array}$ \\
\hline \multirow{3}{*}{$\begin{array}{l}\text { Cardio- } \\
\text { vascular } \\
\text { system } \\
\text { lesions } \\
\text { (5 cases) }\end{array}$} & (2) Cardiomyopathy & (2) AFI \\
\hline & $\begin{array}{l}\text { (2) Congestive cardiac } \\
\text { failure (CCF) }\end{array}$ & (2) AFI \\
\hline & $\begin{array}{l}\text { IPH with CCF in a case of } \\
\text { rheumatic heart disease }\end{array}$ & $\begin{array}{l}\text { ARDS with septic } \\
\text { shock }\end{array}$ \\
\hline \multirow{5}{*}{$\begin{array}{c}\text { Central } \\
\text { nervous } \\
\text { system } \\
\text { lesions } \\
\text { (5 cases) }\end{array}$} & $\begin{array}{c}\text { Raised ICT f/g cerebral } \\
\text { oedema }\end{array}$ & $\begin{array}{c}\text { Tuberculoma in } \\
\text { seropositive male }\end{array}$ \\
\hline & Cerebral oedema with IPH & $\begin{array}{c}\begin{array}{c}\text { Hepatorenal } \\
\text { syndrome }\end{array} \\
\end{array}$ \\
\hline & $\begin{array}{c}\text { Cerebral oedema f/g } \\
\text { bilateral thalamic infarct }\end{array}$ & $\begin{array}{c}\text { Japanese B } \\
\text { encephalitis? TBM? }\end{array}$ \\
\hline & $\begin{array}{c}\text { Cerebral oedema with } \\
\text { thalamic infarct in a lupus } \\
\text { nephritis }\end{array}$ & $\begin{array}{c}\text { Tuberculous } \\
\text { pericarditis with } \\
\text { vasculitis }\end{array}$ \\
\hline & $\begin{array}{c}\text { Subarachnoid } \\
\text { haemorrhages f/g rupture } \\
\text { of aneurysm of MCA with } \\
\text { cirrhosis of liver and fungal }\end{array}$ & AFI \\
\hline
\end{tabular}

\begin{tabular}{|c|c|c|}
\hline & $\begin{array}{c}\text { endocarditis in a case of } \\
\text { cellulitis }\end{array}$ & \\
\hline \multirow{2}{*}{$\begin{array}{c}\text { Hepatic } \\
\text { lesions } \\
\text { (2 cases) }\end{array}$} & $\begin{array}{c}\text { Hepatocellular failure in a } \\
\text { case of panlobular hepatic } \\
\text { necrosis }\end{array}$ & $\begin{array}{c}\text { Tuberculous } \\
\text { meningitis }\end{array}$ \\
\cline { 2 - 3 } & $\begin{array}{c}\text { Submassive hepatic } \\
\text { necrosis }\end{array}$ & AFI \\
\hline \multirow{2}{*}{$\begin{array}{c}\text { 0thers } \\
\text { 2 cases) }\end{array}$} & $\begin{array}{c}\text { Pulmonary oedema with } \\
\text { hepatorenal syndrome } \\
\text { (MODS) }\end{array}$ & Septic shock \\
\cline { 2 - 3 } & Shock with ARDS & AFI \\
\hline
\end{tabular}

Table 7: Class II Discrepancy - Non-Infectious Causes ( $N=22)$

We have detected one case of fungal endocarditis which was missed clinically, but it was added to non-infectious causes as subarachnoid haemorrhages was the immediate cause of death.

Class III discrepancies included 2 cases, one was diagnosed as chronic pyelonephritis and other was multiple renal infarcts on post-mortem examinations, which were missed clinically. Class IV discrepancies showed 2 cases; one was rheumatic valvulitis and the other was diabetic nephropathy.

\begin{tabular}{|c|c|c|}
\hline $\begin{array}{c}\text { Post-mortem cause of } \\
\text { Death }\end{array}$ & Clinical Diagnosis & Discrepancy \\
\hline $\begin{array}{l}\text { Hepatocellular necrosis } \\
\text { with moderately } \\
\text { differentiated SCC of } \\
\text { oesophagus }\end{array}$ & DIC with jaundice & \multirow{3}{*}{ Class I $(n=3)$} \\
\hline $\begin{array}{c}\text { Hepatocellular } \\
\text { carcinoma with } \\
\text { cirrhosis }\end{array}$ & $\begin{array}{l}\text { Septic shock with } \\
\text { hepatitis with } \\
\text { seizure }\end{array}$ & \\
\hline $\begin{array}{l}\text { Infiltrating moderately } \\
\text { differentiated SCC of } \\
\text { oesophagus }\end{array}$ & $\begin{array}{l}\text { Severe anaemia in a } \\
\text { viable abortus }\end{array}$ & \\
\hline $\begin{array}{c}\text { Respiratory failure } \\
\text { following } \\
\text { adenocarcinoma of } \\
\text { lung }\end{array}$ & $\begin{array}{l}\text { Interstitial } \\
\text { pneumonia type II } \\
\text { respiratory failure }\end{array}$ & \multirow[t]{2}{*}{ Class II $(n=2)$} \\
\hline $\begin{array}{l}\text { Disseminated small } \\
\text { round cell malignancy }\end{array}$ & $\begin{array}{l}\text { Quadriparesis with } \\
\text { cervical myopathy } \\
\text { rule out Koch's or } \\
\text { lymphoma }\end{array}$ & \\
\hline \multicolumn{3}{|c|}{ Table 8: Neoplastic Causes } \\
\hline
\end{tabular}

*Abbreviation: DIC- disseminated intravascular coagulation, SCC- squamous cell carcinoma

\section{DISCUSSION}

In our study, there was substantial increase in annual autopsy rates. This may be because the study was conducted in a large public hospital, which is the first major referral hospital and caters to all trauma and disaster cases. High autopsy rate was also shown by Cameron and McGoogan.[4] which helps to reduce a possible bias due to only difficult cases being autopsied.

Majority of the autopsied patients in present study were in the age group of 21-40 years i.e. 82 cases (58.15\%). The MICU study done by Campion et al..[5] showed that maximum autopsies i.e. $60 \%$ were performed in the age group of 16-34 years which is concordant with our study.

In present study Male-to-female ratio was 1:1.47, while in other MICU studies like Maris $C$ et al.[6] and Aline Fusco et al.[7] male-to-female ratio was 1.5:1 and 1.72:1 respectively, which is discordant with our study. Female preponderance in 
our study can be explained by the fact that there were deaths in MICU due to pregnancy related complications.

Out of total 141 cases, the post-mortem diagnosis were matched with clinical diagnosis in 78 cases (55.32\%). Thus, overall discrepancies were found in 63 cases (44.68\%), which is comparable to MICU studies (Table 9).

\begin{tabular}{|c|c|c|c|c|}
\hline Studies & $\begin{array}{l}\text { Years of } \\
\text { Study }\end{array}$ & $\begin{array}{c}\text { Number } \\
\text { of } \\
\text { Autop- } \\
\text { sies }\end{array}$ & $\begin{array}{c}\text { Overall } \\
\text { Discre- } \\
\text { pancies } \\
(\%)\end{array}$ & $\begin{array}{c}\text { Major } \\
\text { Discre- } \\
\text { pancies } \\
\text { (Class I \& } \\
\text { II) \% }\end{array}$ \\
\hline $\begin{array}{l}\text { Tai et } \\
\text { al. } .^{[8]}\end{array}$ & 1994-1995 & 91 & 19.8 & 8.7 \\
\hline $\begin{array}{l}\text { Blosser } \\
\text { et al. }{ }^{[9]}\end{array}$ & 1994-1995 & 41 & 34 & 27 \\
\hline $\begin{array}{l}\text { Perkin G } \\
\text { et al.[10] }\end{array}$ & $1998-2001$ & 49 & 55 & 39 \\
\hline $\begin{array}{c}\text { Podbreg } \\
\text { ar et } \\
\text { al.[11] }\end{array}$ & 2001 & 126 & 52 & 10.5 \\
\hline $\begin{array}{l}\text { Maris C } \\
\text { et al }\end{array}$ & 2004-2005 & 289 & 21 & 19 \\
\hline $\begin{array}{l}\text { Aline } \\
\text { Fusco et } \\
\text { al. }\end{array}$ & $2003-2006$ & 98 & 57.14 & 50 \\
\hline $\begin{array}{l}\text { Present } \\
\text { Study }\end{array}$ & 2011-2014 & 141 & 44.68 & 41.84 \\
\hline
\end{tabular}

In our study class I discrepancies were found in 31 cases of total 63 discrepant cases (49.21\%), which is concordant with a MICU study of Tai et al.[8] who reported $44 \%$ (8 of 18) of class I errors.

A MICU study done by Roosen J et al.[12] showed that class I errors were $16 \%$ and class II errors were $10 \%$ of the total study population, while in our study class I discrepancies were $21.99 \%$ and class II discrepancies were $19.86 \%$ of the total study population. Thus in both the studies, class I errors were more than class II.

The cases in which duration of MICU stay was less than 24 hours showed higher percentage of discrepancies (41.27\%), major discrepancies were high amongst it. Cases with extended hospital stay get time for investigation and diagnostic test like blood culture.

In present study non-infectious cause of death were seen in 71 cases, of which 33 cases ( $46.48 \%$ ) were missed clinically and major discrepancies were seen in 29 cases. Minor discrepancies were seen in 4 cases. Among the total 65 infectious causes, clinical diagnosis was missed in 25 cases (38.46\%). These discrepancies in infectious causes included 21 cases in class I category and of 4 cases in class II category. In a study conducted by Lion and Bonds. ${ }^{[13]}$ showed that 59 cases $(43.1 \%)$ infectious causes were missed on clinical diagnosis. The study by Goldman et al.[3] showed that infections were missed clinically in $24 \%$.

In our study, most common class I discrepancies were seen as infectious aetiology. The study conducted by Winters $B$ et al.[14] also showed that infections (41\%) were most common class I errors, which includes pneumonia and aspergillosis. In our study, commonly missed infections were of tuberculosis and pneumonia. Tuberculosis was missed in 10 cases $(47.61 \%)$ of total missed infections. These were 5 cases of disseminated tuberculosis, 3 cases of tuberculous meningitis and 2 cases of tuberculous bronchopneumonia. This maybe because of atypical presentation of tuberculosis, which made the clinician difficult to diagnose it. All the missed tuberculosis were classified in class I discrepancy as antituberculous treatment would have improved patient's survival.

In an ICU study conducted by Abdullah A et al.[15] showed that 11 cases $(33.34 \%)$ of tuberculosis out of 33 were not diagnosed during hospitalization and 7 of them died. These cases were diagnosed as tuberculosis based on positive Mycobacterium culture later on either post discharge from hospital or at autopsy. In present study second missed infection in class I discrepancy was pneumonia, which were 8 cases in which 2 cases were of tuberculous aetiology which are already mentioned.

The study done by Kotovicz F et al.[16] also showed that pneumonia was second most common missed infection in their study. Non-infectious causes were commonly missed clinically in our study. The study by Vougiouklakis T et al.[17] also showed non-infectious conditions were commonly missed, of which IHD (72.4\%) was the most common followed by pulmonary embolism. Myocardial infarction was the most common missed class I error of non-infectious cause. This finding is consistent with Gavin Perkin et al.[10] These authors suggested that the index of suspicion for ischemic heart disease is inappropriately low in the critically ill patient. Although an electrocardiogram is performed almost every day in our MICU, post-mortem examination still revealed myocardial infarction as major discrepancy in 4 patients. It may be because of very short duration of MICU stay. Our observations reinforce the importance of the post-mortem examination in identifying suspected or unexpected diagnoses, even in patients receiving close monitoring in intensive care.

In present study 3 cases of central nervous system lesions were included in class I error, all were of intracranial bleed. Kotovicz $F$ et al.[16] showed that ischemic or haemorrhagic intracranial vascular disease was not clinically recognized in four patients.

Most commonly missed major diagnoses with no impact on survival (Class II discrepancy) were of non-infectious aetiology, of which cardiorespiratory lesions were most common. Amongst the respiratory lesions, diffuse intrapulmonary haemorrhages were most commonly missed which may be because of complication of another main disorder, thus making their diagnosis problematic. Stephen M Pastores.[18] showed in their study that majority of class II discrepancies were due to cardiopulmonary complications (70).

In our study, minor discrepancies were seen in 4 cases of which 2 cases were in class III and 2 cases were in class IV. Study done by Perkin GD et al.[10] showed 6 cases $(16 \%)$ in Goldman class III/IV discrepancies.

All the 5 cases of neoplastic aetiology were missed clinically. The cause may be low level of suspicion of malignancy and low sensitivity of investigation.

\section{CONCLUSION}

The autopsy should be seen as an extension of the diagnostic investigation, which can help the clinician in refining the diagnostic skills. The post-mortem examination should not be seen as a means of clinical malpractice as critical patients cannot give full history.

Our study stresses that routine autopsy is still very useful in MICU and emphasis must be placed on autopsy evaluation 
for the improvement of the quality of patient care. Without the autopsy people die in vain, the living are denied what they can learn from the dead. Death and dying are catastrophic, but through the post-mortem examination, the knowledge to postpone the death and make life more valuable can be salvaged.

\section{REFERENCES}

1. Gambino SR. The autopsy. The ultimate audit. Arch Pathol Lab Med 1984;108(6):444-5.

2. Dan EM, Kunle AE, Nneka UI, et al. An audit of medical autopsy: experience at the university of uyo teaching hospital (UUTH), Niger delta region, Nigeria. Indian J Med Sci 2011;65(11):502-9.

3. Goldman L, Sayson R, Robbins S, et al. The value of the autopsy in three medical eras. $\mathrm{N}$ Engl J Med 1983;308(17):1000-5.

4. Cameron HM, Mc Googan E, Watson H. Necropsy: a yardstick for clinical diagnoses. $\mathrm{Br}$ Med J 1980;281(6246):985-8.

5. Campion EW, Reder VA, Mulley AG, et al. Age and the declining rate of autopsy. J Am Geriatr Soc 1986;34(12):865-8.

6. Maris C, Martin B, Creteur J, et al. Comparison of clinical and post-mortem findings in intensive care unit patients. Virchows Arch 2007;450(3):329-33.

7. Fares AF, Fares J, Fares GF, et al. Clinical and pathological discrepancies and cardiovascular findings in 409 consecutive autopsies. Arq Bras Cardiol 2011;97(6):44955.

8. Tai DY, El-Bilbeisi H, Tewari S, et al. A study of consecutive autopsies in a medical ICU : a comparison of clinical cause of death and autopsy diagnosis. Chest 2001;119(2):530-6.

9. Blosser SA, Zimmerman HE, Stauffer JL. Do autopsies of critically ill patients reveal important findings that were clinically undetected? Crit Care Med 1998;26(8):1332-6.
10. Perkins GD, McAuley DF, Davies S, et al. Discrepancies between clinical and postmortem diagnoses in critically ill patients: an observational study. Crit Care 2003;7(6):R129-32.

11. Podbregar M, Voga G, Krivec B, et al. Should we confirm our clinical diagnostic certainty by autopsies? Intensive Care Med 2001;27(11):1750-5.

12. Roosen J, Frans E, Wilmer A, et al. Comparison of premortem clinical diagnoses in critically iII patients and subsequent autopsy findings. Mayo Clin Proc 2000;75(6):562-7.

13. Lian A Bonds, Loretta Gaido. Infectious diseases detected at autopsy at an urban public hospital, 1996-2001. Am J Clin Pathol 2003;119:866-72.

14. Winters B, Custer J, Galvagno SM Jr, et al. Diagnostic errors in the intensive care unit: a systematic review of autopsy studies. BMJ Qual Saf 2012;21(11):894-902.

15. Abdullah A Alshimemeri, Yaseen M Arabi, Hamdan AlJahdali, et al. Clinical presentation and outcome of patients diagnosed with active pulmonary tuberculosis in a large critical care unit. Crit Care \& Shock 2011;14:16.

16. Fabiana Kotovicz, Thais Mauad, Paulo HN Saldiva. Clinico-pathological discrepancies in a general university hospital in São Paulo, Brazil. Clinics 2008;63(5):581-588.

17. Vougiouklakis T, Fragkouli K, Mitselou A, et al. A comparison of the provisional clinical diagnosis of death with autopsy findings. Rom J Leg Med 2011;19(3):177182.

18. Pastores SM, Dulu A, Voigt L, et al. Premortem clinical diagnoses and postmortem autopsy findings: discrepancies in critically ill cancer patients. Crit Care 2007;11(2):R48. 